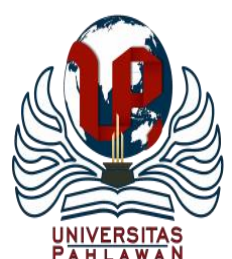

Jurnal Abdidas Volume 2 Nomor 6 Tahun 2021 Halaman 1472- 1478

JURNAL ABDIDAS

http://abdidas.org/index.php/abdidas

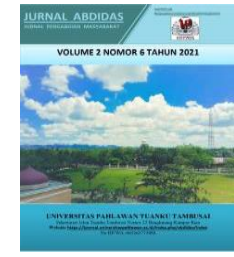

\title{
Penerapan Pola Pemberian Makanan dalam Pencegahan Kejadian Stunting pada Balita
}

\author{
Linda Wati ${ }^{1 凶}$ Husni $^{2}$, Fadhilatul Hasnah ${ }^{3}$, Dian Paramitha Asyari ${ }^{4}$ \\ Kebidanan, STIKes Alifah Padang, Indonesia ${ }^{1,2}$ \\ Kesehatan Masyarakat, STIKes Alifah Padang, Indonesia ${ }^{3,4}$ \\ E-mail : $\underline{\text { lindawati.akbid@gmail.com }}{ }^{1} \underline{\text { husnippk@gmail.com }}{ }^{2} \underline{\text { fhasnah5@gmail.com }}^{3}$ \\ dianparamitha6692@gmail.com ${ }^{4}$
}

\begin{abstract}
Abstrak
Masalah stunting terutama yang terjadi pada masa balita dianggap serius dikarenakan kondisi stunting pada masa balita dapat mengakibatkan keterlambatan perkembangan motorik dan menurunnya tingkat kecerdasan. Metode pelaksanaan pengabdian yang digunakan dalam mengatasi permasalahan mengenai Penerapan Pemberian Pola Makan dalam Pencegahan Stunting pada Anak Balita secara langsung ke sasaran dengan memberikan pendidikan kesehatan dengan menggunakan penyuluhan agar orang tua tertarik dan dapat mengaplikasikan dalam kehidupan sehari-hari khususnya tentang kesiapan nutrisi pada anak balita. Tujuannya untuk meningkatkan pengetahuan dan kesiapan ibu-ibu yang mempunyai anak balita dan keluarga tentang Penerapan Pemberian Pola Makan dalam Pencegahan Stunting pada Anak Balita. Kegiatan dilakukan di Puskesmas Lubuk Buaya Padang. Melalui kegiatan ini, terjadi peningkatkan pengetahuan ibu mengenai pentingnya penerapan pemberian pola makan dalam pencegahan stunting pada anak balita. Sehingga dapat diharapkan bisa meningkatkan angka kecukupan gizi balita dan mencegah terjadinya kejadian gizi kurang atau gizi buruk, khususnya di wilayah kerja Puskesmas Lubuk Buaya.
\end{abstract}

Kata kunci : stunting, balita, pola makan

Abstract

Stunting problems, especially those that occur in toddlers are considered serious because stunting conditions in toddlers can result in delays in motor development and decreased levels of intelligence. The method of implementing the service used in overcoming problems regarding the Application of Feeding Patterns in Preventing Stunting in Toddlers is directly to the target by providing health education by using counseling so that parents are interested and can apply it in everyday life, especially regarding nutritional readiness for toddlers. The aim is to increase the knowledge and readiness of mothers with toddlers and their families regarding the Application of Feeding Patterns in Preventing Stunting in Toddlers. The activity was carried out at the Lubuk Buaya Padang Health Center. Through this activity, there was an increase in mother's knowledge about the importance of implementing a diet in preventing stunting in children under five. So that it can be expected to increase the nutritional adequacy of children under five and prevent the occurrence of malnutrition or malnutrition, especially in the working area of the Lubuk Buaya Health Center.

Keywords: stunting, toddlers, diet

Copyright (c) 2021 Linda Wati, Husni, Fadhilatul Hasnah, Dian Paramitha Asyari

$\triangle$ Corresponding author

Address : STIKes Alifah Padang

Email : lindawati.akbid@gmail.com

ISSN 2721-9224 (Media Cetak)

DOI $\quad$ : https://doi.org/10.31004/abdidas.v2i6.543

ISSN 2721- 9216 (Media Online) 
1473 Penerapan Pola Pemberian Makanan dalam Pencegahan Kejadian Stunting pada Balita - Linda Wati, Husni, Fadhilatul Hasnah, Dian Paramitha Asyari

DOI: https://doi.org/10.31004/abdidas.v2i6.543

\section{PENDAHULUAN}

Stunting adalah gangguan pertumbuhan fisik yang sudah lewat, berupa penurunan kecepatan pertumbuhan dalam perkembangan manusia yang merupakan dampak utama dari gizi kurang. Gizi kurang merupakan hasil dari ketidak seimbangan faktor-faktor pertumbuhan (faktor internal dan eksternal). Gizi kurang dapat terjadi selama beberapa periode pertumbuhan, seperti masa kehamilan, masa perinatal, masa menyusui, bayi dan masa pertumbuhan (masa anak). Hal ini juga bisa disebabkan karena defisiensi dari berbagai zat gizi, misalnya mikronutrien, protein atau energi (Setiawan, 2015) Status gizi ibu hamil sangat mempengaruhi keadaan kesehatan dan perkembangan janin (Khorun Ni'mah, 2015). Gangguan pertumbuhan dalam kandungan dapat menyebabkan berat lahir rendah (WHO, 2014 dalam Khorun Ni’mah, 2015).

Status stunting pada balita muncul dari interaksi berbagai faktor. Faktor risiko stunting melibatkan status gizi ibu sejak masa hamil dan pola asuh ibu setelah lahir. Faktor risiko stunting adalah ibu pendek, berat bayi lahir rendah, ASI tidak eksklusif, penyakit infeksi, defisiensi protein, dan defisiensi zat gizi mikro terutama zink dan zat besi (Hendrick et al., 2013). Stunting merupakan prediktor buruknya kualitas sumber daya manusia yang selanjutnya akan berpengaruh pada pengembangan potensi bangsa (Unicef, 2013).

Nepal menunjukkan bahwa bayi dengan berat lahir rendah mempunyai risiko yang lebih tinggi untuk menjadi stunting (Paudel, et al., 2012). Panjang lahir bayi juga berhubungan dengan kejadian stunting. Penelitian di Kendal menunjukkan bahwa bayi dengan panjang lahir yang pendek berisiko tinggi terhadap kejadian stunting pada balita (Meilyasari dan Isnawati, 2014). Faktor lain yang berhubungan dengan stunting adalah asupan ASI Eksklusif pada balita. Penelitian di Ethiopia Selatan membuktikan bahwa balita yang tidak mendapatkan ASI eksklusif selama 6 bulan berisiko tinggi mengalami stunting (Fikadu, et al., 2014).

Masalah stunting terutama yang terjadi pada masa balita dianggap serius dikarenakan kondisi stunting pada masa balita dapat mengakibatkan keterlambatan perkembangan motorik dan menurunnya tingkat kecerdasan. Dampak lain yang timbul yaitu dapat menyebabkan depresi fungsi imunitas, perubahan metabolik, penurunan perkembangan motorik, menurunnya nilai kognitif dan nilai akademik. Anak yang mengalami stunting akan timbul dampak dalam jangka waktu yang panjang, diantaranya adalah beresiko obesitas, glucose tolerance, penyakit jantung koroner, hipertensi, osteoporosis, penurunan perfoma dan produktifitas (El-taguri et al, 2015).

Asupan makanan berkaitan dengan kandungan nutrisi (zat gizi) yang terkandung di dalam makanan yang dimakan. Dikenal dua jenis nutrisi (zat gizi) yang terkandung didalam makanan yang dimakan. Ada dua jenis nutrisi yaitu makronutrisi dan mikronutrisi. Makronutrisi merupakan nutrisi yang menyediakan kalori atau energi, diperlukan untuk pertumbuhan, metabolisme, dan fungsi tubuh lainnya. Makronutrisi ini diperlukan tubuh dalam jumlah yang besar, terdiri dari karbohidrat, protein, dan lemak. Nutrisi (zat gizi) merupakan bagian yang 
1474 Penerapan Pola Pemberian Makanan dalam Pencegahan Kejadian Stunting pada Balita - Linda Wati, Husni, Fadhilatul Hasnah, Dian Paramitha Asyari

DOI: https://doi.org/10.31004/abdidas.v2i6.543

penting dari kesehatan dan pertumbuhan. Nutrisi yang baik berhubungan dengan peningkatan kesehatan bayi, anak-anak, dan ibu, sistem kekebalan yang kuat, kehamilan dan kelahiran yang aman, resiko rendah terhadap penyakit tidak menular seperti diabetes dan penyakit jantung, dan umur yang lebih panjang (WHO, 2011).

Apabila defisiensi (kekurangan) asupan gizi ini terjadi pada ibu hamil, maka janin yang dikandung dapat kekurangan gizi. Wanita hamil yang kekurangan gizi bisa melahirkan bayi dengan berat badan rendah. Hal ini bahkan dapat terjadi pada masa konsepsi (pertumbuhan), pada kondisi (calon) ibu kekurangan gizi sehingga janin tidak dapat tumbuh dalam kondisi optimal. Kenyataan itu bisa bertambah parah bila pemberian ASI kurang, pemberian makanan pendamping ASI terlambat, kuantitas serta kualitas makanan tambahan kurang, dan terjadi gangguan penyerapan zat gizi akibat infeksi disaluran cerna. Kondisi ini akan mengakibatkan gangguan tinggi badan pada anak, sehingga tinggi badannya tidak sesuai dengan usianya atau lebih pendek daripada teman sebayanya (Setiawan, 2010).

Manusia membutuhkan makanan untuk kelangsungan hidupnya, makanan merupakan sumber energi untuk menunjang semua kegiatan atau aktivitas manusia. Energi dalam tubuh manusia dapat timbul dikarenakan adanya pembakaran karbohidrat, protein dan lemak. Dengan demikian agar manusia selalu tercukupi energinya diperlukan pemasukan zat-zat makanan yang cukup pula kedalam tubuhnya. Manusia yang kurang makanan akan lemah, baik daya kegiatan pekerjaan fisik atau daya pemikirannya karena kurangnya zat-zat makanan yang diterima tubuhnya yang dapat menghasilkan energi (Fitri, (2012).

Pemberian makan pada anak balita bertujuan untuk mendapatkan zat gizi yang cukup. Zat gizi sangat dibutuhkan bagi pertumbuhan dan perkembangan anak. Disamping itu zat gizi berperan dalam memelihara dan memulihkan kesehatan. Zat gizi pada anak sangat penting karena pertumbuhan, perkembangan dan kecerdasan anak ditentukan sejak bayi bahkan sejak dalam kandungan (Ahmad, 2012).

Bedasarkan masalah kesehatan mitra yaitu Puskesmas Lubuk Buaya Padang, yang muncul pada anak balita khususnya masalah kesehatan stunting yang disebabkan kekurangan nutrisi. Adapun dapat diuraikan bahwa permasalahan tersebut disebabkan beberapa faktor penyebab penyebab seperti; a) Banyaknya keluhan dari orang tua anak balita yang mengatakan kalau anaknya tidak mau makan dan tidak mengerti pola makan yang benar. B) Kurangnya dukungan dari petugas petugas kesehatan untuk memberikan informasi tentang masalah pola makan bagi anak balita. c) Kurangnya informasi tentang masalah penyebab stunting sehingga kurangnya kesiapan orang tua menghadapi perkembangan anak sehingga mengakibatkan sehingga anak bakita mengalami perkembangan yang tidak sesuai.

Pengetahuan yang baik dirasa penting bagi ibu-ibu saat masa-masa anak balita ini, karena pengetahuan merupakan salah satu komponen dalam pembentukan sikap seseorang, bisa dikatakan apabila pengetahuan ibu-ibu yang mempunyai anak balita tentang pola makan tidak 
1475 Penerapan Pola Pemberian Makanan dalam Pencegahan Kejadian Stunting pada Balita - Linda Wati, Husni, Fadhilatul Hasnah, Dian Paramitha Asyari

DOI: https://doi.org/10.31004/abdidas.v2i6.543

memadai akan berdampak pada perkembangan anak sehingga mengakibatkan sehingga anak bakita mengalami perkembangan yang tidak sesuai. Maka dibutuhkan pendidikan kesehatan untuk menambah pengetahuan dan memberikan informasi yang adekuat dan tepat.

Terlaksananya pendidikan kesehatan membutuhkan media atau alat peraga supaya apa yang disampaikan sesuai dengan apa yang diharapkan. Salah satu media pendidikan kesehatan yang paling banyak diminati khususnya anak-anak dan ibu-ibu adalah media penyuluan. Media ini merupakan media yang sesaui dengan perkembangan zaman sekarang yang mencakup indera penglihatan dan pendengaran. Berdasarkan permasalah yang diuraikan maka upaya meningkatkan pengetahuan pola makan pada anak balita yang dapat dilakukan adalah dengan memberikan pendidikan kesehatan tentang kesiapan orangtua menghadapi masa perkembangan dan pertumbuan anak balitanya yaitu memberikan pengetahuan, informasi dan dapat mengaplikasikan dalam kehidupan seharihari. Oleh karena itu, beberapa uraian solusi permasalahan yang akan dilakukan pada pengabdian masyarakat kepada ibu-ibu yang mempunyai anak balita dan memberikan umpan balik pada kegiatan tersebut. Adapun solusi yang dapat dilakukan pada kegiatan pengabdian masyarakat adalah sebagai berikut :

1. Melakukan observasi awal terhadap ibu-ibu yang mempunyai anak balita di Pkm Lubuk Buaya yaitu melakukan pre test yaitu menyebarkan kuesioner terkait pola makam pada anak balita.
2. Melakukan diskusi dengan pimpinan $\mathrm{Pkm}$ untuk perencanaan dan menyediakan tempat pelaksanaan memberikan informasi kesehatan.

3. Memberikan pendidikan kesehatan tentang kesiapan orangtua menghadapi masa perkembangan dan pertumbuan anak balitanya dengan penyuluan dan merancang proses pelaksanaan kegiatan.

\section{METODE}

Metode pelaksanaan yang digunakan dalam mengatasi permasalahan stunting pada anak balita adalah secara langsung ke sasaran dengan pendidikan kesehatan tentang kesiapan orang tua menghadapi masa perkembangan dan pertumbuhan anak balitanya dengan menggunakan media penyuluhan agar ibu-ibu yang mempunyai anak balita tertarik dan dapat mengaplikasikan dalam kehidupan sehari-hari. Metode pelaksanaan yang akan dikerjakan adalah sebagai berikut :

1. Tahap Awal : Persiapan

Pada tahap persiapan kegiatan yang dilakukan meliputi :

1) Pengurusan surat perizinan dari Sekolah Tinggi Ilmu Kesehatan Alifah Padang kel lokasi yaitu ke Pkm Lubuk Buaya.

2) Penyusunan daftar observasi untuk mendapatkan informasi tentang Kesiapan ibu-ibu yang mempunyai anak balita menghadapi masa perkembangan dan pertumbuhan anak balitanya.

3) Kegiatan persiapan akan dilakukan pada bulan Desember 2020 sampai 
1476 Penerapan Pola Pemberian Makanan dalam Pencegahan Kejadian Stunting pada Balita - Linda Wati, Husni, Fadhilatul Hasnah, Dian Paramitha Asyari

DOI: https://doi.org/10.31004/abdidas.v2i6.543

Januari 2021, dengan dibantu oleh mahasiswa sebanyak 5 orang. Hasil observasi digunakan sebagai bahan dalam penyusunan materi kegiatan pengabdian.

2. Langkah 1 : Persamaan Persepsi dan Penyampaian Gambaran Kegiatan

1) Melakukan koordinasi dengan Pimpinan dan Petugas Puskesmas di Puskesmas Lubuk Buaya untuk perencanaan pelaksananan kegiatan.

2) Persamaan persepsi kegiatan.

3) Mempersiapkan perlengkapan pelaksanaan kegiatan seperti laptop, infocus, layar infocus dan sound system, menyediakan leaflet dan poster.

3. Langkah 2 : Pengambilan Data Awal dan Observasi

1) Observasi dilakukan untuk mendapatkan informasi tentang penerapan pola makan pada anak balita.

2) Pengolahan data secara deskriptif meliputi pengetahuan ibu-ibu tentang penerapan pola makan pada anak balita.

3) Persiapan materi kegiatan pengabdian.

4. Langkah 3 : Pelaksanaan

Tahap pelaksanaan kegiatan pengabdian dilakukan melalui 2 tahap yaitu sebagai berikut :

1) Tahap 1

Pada tahap 1 kegiatan yang akan dilakukan adalah membentuk group kelompok kecil yang terdiri dari petugas puskesmas, narasumber dan mahasiswa utnuk memberikan edukasi tentang penerapan pola makan pada anak balita, kemudian merancang tempat pelaksanaan kegiatan dengan menyediakan perlengkapan penyuluhan seperti laptop, infocus, layar infocus dan sound system yang mendukung pelaksanaan kegiatan.

2) Tahap 2

Pada tahap 2 kegiatan yang akan dilakukan adalah memberikan edukasi tentang penerapan pola makan pada anak balita dengan media penyuluhan kepada ibu-ibu yang mempunyai anak balita yang di fasilitator oleh petugas puskesmas dan dibantu oleh 5 orang mahasiswa.

5. Langkah 4 : Evaluasi

Evaluasi dilakukan pada setaip tahap kegiatan dan akhir kegiatan pengabdian. Pelaksanaan evaluasi dilakukan dengan cara observasi, dan data kualitatif dari ibu-ibu yang mempunyai anak balita dan petugas puskesmas di Puskesmas Lubuk Buaya.

\section{HASIL DAN PEMBAHASAN}

Pengabdian kepada masyarakat telah dilakukan pada hari senin tanggal 18 Januari 2021 dengan jumlah peserta 30 orang masyarakat. Dimana dosen dan mahasiswa melakukan Penyuluhan Penerapan Pemberian Pola Makan Dalam Pencegahan Stunting Pada Anak Balita di Puskesmas Lubuk Buaya Padang.

Kegiatan ini diawali kunjungan ke Puskesmas Lubuk Buaya Padang. Kunjungan dilakukan dalam rangka penyampaian tujuan 
1477 Penerapan Pola Pemberian Makanan dalam Pencegahan Kejadian Stunting pada Balita - Linda Wati, Husni, Fadhilatul Hasnah, Dian Paramitha Asyari

DOI: https://doi.org/10.31004/abdidas.v2i6.543

kegiatan, persamaan persepsi dan kerjasama dengan mitra. Hasil dari diskusi bersama mitra, diperoleh kesimpulan perlu upaya meningkatkan pengetahuan pola makan pada anak balita. Oleh karena itu, tim pengabdian bekerja sama dengan mitra dan melaksanakan kegiatan edukasi pengetahuan pola makan pada anak balita kepada ibu di wilayah kerja mitra.

Adapun materi yang dipaparkan pada saat kegiatan mengenai stunting, penyebabnya dan pola makan sebagai upaya pencegahan stunting. Masalah stunting terutama yang terjadi pada masa balita dianggap serius dikarenakan kondisi stunting pada masa balita dapat mengakibatkan keterlambatan perkembangan motorik dan menurunnya tingkat kecerdasan. Dampak lain yang timbul yaitu dapat menyebabkan depresi fungsi imunitas, perubahan metabolik, penurunan perkembangan motorik, menurunnya nilai kognitif dan nilai akademik. Anak yang mengalami stunting akan timbul dampak dalam jangka waktu yang panjang, diantaranya adalah beresiko obesitas, glucose tolerance, penyakit jantung koroner, hipertensi, osteoporosis, penurunan perfoma dan produktifitas (El-taguri et al, 2015).

Asupan makanan berkaitan dengan kandungan nutrisi (zat gizi) yang terkandung di dalam makanan yang dimakan. Dikenal dua jenis nutrisi (zat gizi) yang terkandung didalam makanan yang dimakan. Ada dua jenis nutrisi yaitu makronutrisi dan mikronutrisi. Makronutrisi merupakan nutrisi yang menyediakan kalori atau energi, diperlukan untuk pertumbuhan, metabolisme, dan fungsi tubuh lainnya. Makronutrisi ini diperlukan tubuh dalam jumlah yang besar, terdiri dari karbohidrat, protein, dan lemak. Nutrisi (zat gizi) merupakan bagian yang penting dari kesehatan dan pertumbuhan. Nutrisi yang baik berhubungan dengan peningkatan kesehatan bayi, anak-anak, dan ibu, sistem kekebalan yang kuat, kehamilan dan kelahiran yang aman, resiko rendah terhadap penyakit tidak menular seperti diabetes dan penyakit jantung, dan umur yang lebih panjang (WHO, 2011).

Pemberian makan pada anak balita bertujuan untuk mendapatkan zat gizi yang cukup. Zat gizi sangat dibutuhkan bagi pertumbuhan dan perkembangan anak. Disamping itu zat gizi berperan dalam memelihara dan memulihkan kesehatan. Zat gizi pada anak sangat penting karena pertumbuhan, perkembangan dan kecerdasan anak ditentukan sejak bayi bahkan sejak dalam kandungan (Ahmad, 2012).

Setelah pemaparan materi, dilakukan diskusi dan tanya jawab. Lebih dari 15 (lima belas) peserta yang bertanya pada sesi diskusi dan Tanya jawab yang menjadi indikator antusiasme peserta terhadap kegiatan yang dilakukan.

Melalui kegiatan ini, meningkatkan pengetahuan ibu mengenai pentingnya penerapan pemberian pola makan dalam pencegahan stunting pada anak balita. Sehingga tim pengabdi dapat berharap bisa meningkatkan angka kecukupan gizi balita dan mencegah terjadinya kejadian gizi kurang atau gizi buruk, khususnya di wilayah kerja Puskesmas Lubuk Buaya. 
1478 Penerapan Pola Pemberian Makanan dalam Pencegahan Kejadian Stunting pada Balita - Linda Wati, Husni, Fadhilatul Hasnah, Dian Paramitha Asyari

DOI: https://doi.org/10.31004/abdidas.v2i6.543
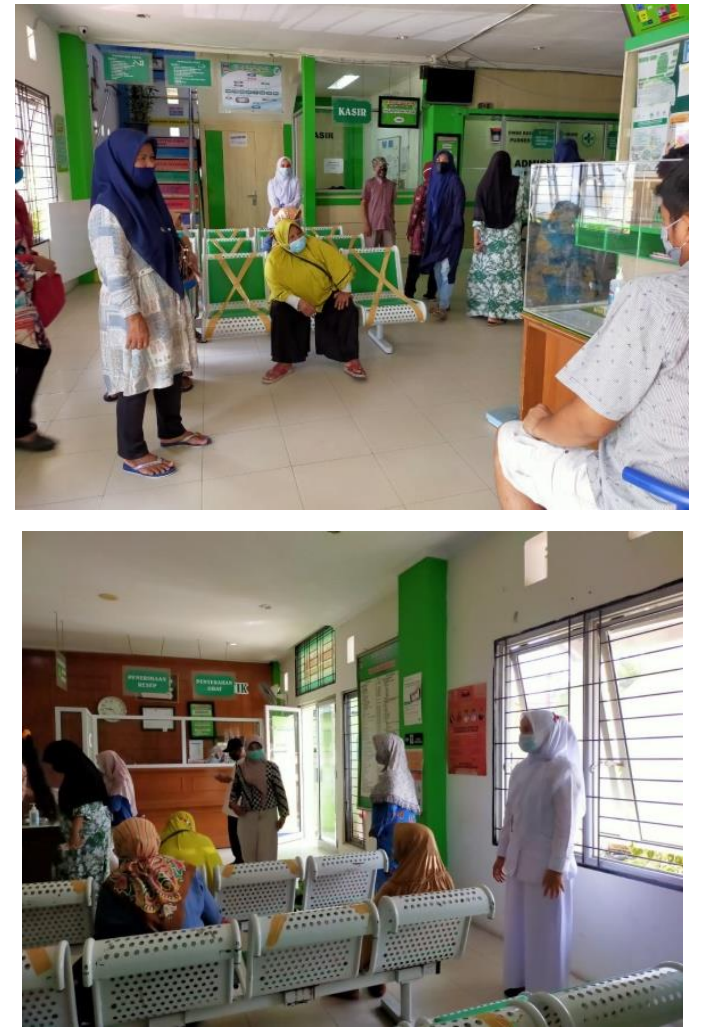

Gambar 1. Kegiatan Edukasi

\section{SIMPULAN}

Masalah stunting terutama yang terjadi pada masa balita dianggap serius dikarenakan kondisi stunting pada masa balita dapat mengakibatkan keterlambatan perkembangan motorik dan menurunnya tingkat kecerdasan. Metode pelaksanaan pengabdian yang digunakan dalam mengatasi permasalahan mengenai Penerapan Pemberian Pola Makan Dalam Pencegahan Stunting Pada Anak Balita secara langsung ke sasaran dengan memberikan pendidikan kesehatan dengan menggunakan penyuluhan agar orang tua tertarik dan dapat mengaplikasikan dalam kehidupan sehari-hari khususnya tentang kesiapan nutrisi pada anak balita. Tujuannya untuk meningkatkan pengetahuan dan kesiapan ibu-ibu yang mempunyai anak balita dan keluarga tentang
Penerapan Pemberian Pola Makan Dalam Pencegahan Stunting Pada Anak Balita. Kegiatan dilakukan di Puskesmas Lubuk Buaya Padang. Melalui kegiatan ini, terjadi peningkatkan pengetahuan ibu mengenai pentingnya penerapan pemberian pola makan dalam pencegahan stunting pada anak balita.

\section{DAFTAR PUSTAKA}

Proyek Kesehatan dan Gizi berbasis Masyarakat Untuk Mengurangi Stunting. In: Corporation MC, editor. Jakarta: MCAIndonesia; 2014.

Rosha BC, Putri DSK, Putri IYS. Determinan Status Gizi Pendek Anak Balita dengan Riwayat Berat Badan Lahir Rendah di Indonesia (BBLR) dI INDONESIA (Analaisis Data Riskesdas 2013). Jurnal Ekologi Kesehatan.2013;12:195-205

Rudert C. Malnutrition in Asia. Vientiane: UNICEF East Asia Pacific; 2014.

Stunting. The Indonesian Journal of Public Health. 2012

Sulastri D. Faktor Determinan Kejadian Stunting pada Anak Usia Sekolah di Kecamatan Lubuk Kilangan Kota Padang. Majalah Kedokteran Andalas. 2012

UNICEF. Ringkasan Kajian Gizi. Jakarta: Pusat Promosi Kesehatan - Kementerian Kesehatan RI; 2012 Aisyah., 